\title{
Lessons Learned from the Design Process of a Learning Management System
}

\author{
Tuncay Sevindik (Phd), Ahmet Başal (Phd) \\ Y1ldız Technical University, Department of Computer and Instructional Technology Education \\ Yildiz Technical University, Department of Foreign Languages Education \\ Istanbul, Turkey \\ sevindik@yildiz.edu.tr; abasal@yildiz.edu.tr
}

\begin{abstract}
Distance education has been spreading throughout the world especially with the increase in ICT. Learning Management System (LMS) is one of the most important dimensions of this educational model. LMS is a software application used for the administration, documentation, tracking, reporting and delivery of the course content. This study will introduce the design process of LMS that was developed by Yildiz Technical University. Based on the lessons learned during and after the design of LMS, it is concluded that users are one of the most important assets of LMS for the improvement of these systems.
\end{abstract}

Keywords-Distance Education, Learning Management Systems, Software

\section{INTRODUCTION}

Distance education is an education model dating back to the early $19^{\text {th }}$ century. With the developments in ICT especially in the last ten years, this model has been transformed. LMS is an application for the delivery of the courses in today's web-based distance education system. Distance teaching may be defined as a set of instructional methods closing the distance between the teachers and students between whom real face-to-face communication is missing with the use of print, electronic or other devices (1).

Distance Learning (DL) is an instructional delivery system that connects learners with educational resources. DL provides educational access to learners not enrolled in educational institutions and can augment the learning opportunities of current students. The implementation of DL is a process that uses available resources and will evolve to incorporate emerging Technologies (2).

Several key features define distance learning. The importance of the teacher - learner communications cannot be overstated.

- the separation of teacher and learner during at least a majority of each instructional process

- separation of teacher and learner in space and/or time

- the use of educational media to unite teacher and learner and carry course content

- the provision of two-way communication between teacher, tutor, or educational agency and learner, and

- control of the learning pace by the student rather than the distance instructor.
Distance learning, sometimes called e-learning, is a formalized teaching and learning system specifically designed to be carried out remotely by using electronic communication.

Popular distance learning technologies include:

-Voice-centered technology, such as $\underline{\mathrm{CD}}$ or MP3 recordings or Webcasts

-Video technology, such as instructional videos, DVDs, and interactive videoconferencing

- Computer-centered technology delivered over the Internet or corporate intranet (3)

Learning Management System (LMS) is one approach to the application of computers to education which holds great potential and important concepts yet is often misunderstood and the term misused (4) LMS is a broad term that is used for a wide range of systems that organize and provide access to online learning services for students, teachers, and administrators. These services usually include access control, provision of learning content, communication tools, and organizations of user groups. Another term that often is used as a synonym to LMS is learning platform (5).

\section{Design AND Programming Process of LEARNING MANAGEMENT SYSTEM}

\section{A. LMS Design Process}

Based on the needs of the learners, teachers and managers, easy-to-be-used modules were planned. The aim was to develop a user-friendly and functional LMS meeting the needs of all participants of the distance education (students-teachers-managers). While developing the LMS, PHP, as the programming language and MySQL as the database were used. HTML 5 and CSS3 were also utilized. jQuery and Javascript were effectively used. With this LMS, three types of authorization were determined: student, teacher and manager.

\section{B. Student, Teacher and Manager Accounts}

With the student account, the students will reach to the classes they are designated, read announcements and contact with the teacher and other students in the system through the use of forum. All the logs related to the student behaviors in the system are kept in the LMS and teachers and managers can follow these logs. 
With the teacher account, the teachers will reach the students in their classes and have control over the forums and announcements and see the class list and behaviors of the students in the system. They also have control over the forums where students and the teacher have different kinds of interactions related to the course content and other subjects determined by the teacher.

With the manager account, the managers can control all the modules in the system (e.g. open-close classes, add announcement, designate teachers and etc. )..

\section{Security}

The users of LMS can reach just the modules open to them in accordance with their authority level under the control of the managers.

\section{Database}

The database of LMS were programmed with MySQL . This database was designed with correlational data model.

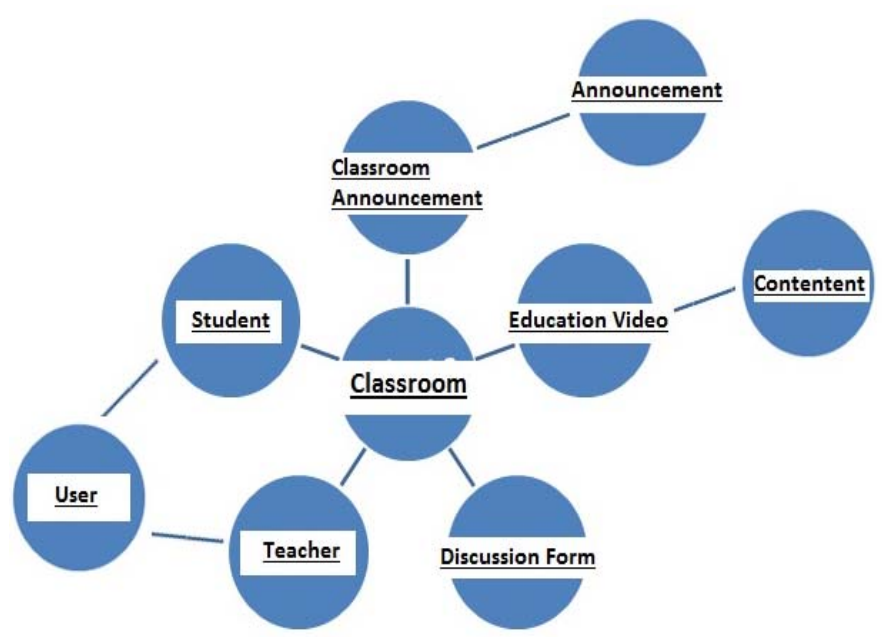

Figure 1. LMS Management Structure of Database

- Student, teacher, announcement, forums and content can be defined for classes.

- Students and teachers can be added to the classes.

- Teacher and the student can be designated for more than one class.

- Discussion forums can be formed for each of the classes or courses.

- Announcements can be published for more than one class at the same time.

- Course content is seen for the designated class or classes.

- More than one course can be designated for a class.

When looked at the design structure of the LMS; main page, course content page, announcement, discussion forum and user behaviors pages can be seen in the following figures.

\section{E. LMS Main Page (Access Page)}

This page includes title, upper-level menu, post-its (explanation notes), access-to-the-system form, and writing fields for the constant explanations. All these segments can be updated-modified by the managers. In designing this and other pages user-friendliness, functionality and appearance were the primary concerns.

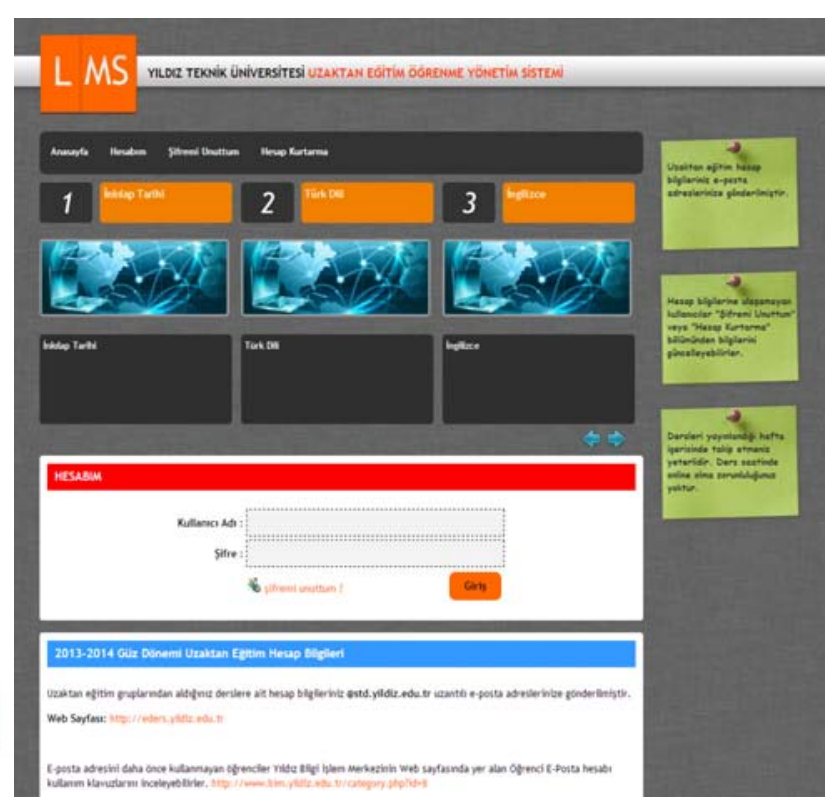

Figure 2. LMS Access Page

\section{LMS MAIN PAGE AFTER THE USER ACCESS}

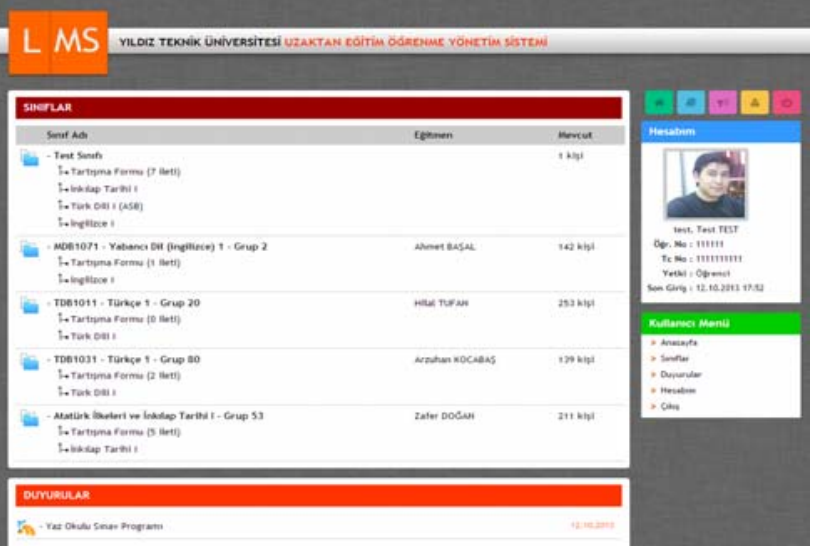

Figure 3. LMS Course Page

All the courses and announcements can be seen by the students at this page.

\section{A. Course Content Page}

This page includes all the course content in different document formats such as text, video, images and documents-files. 


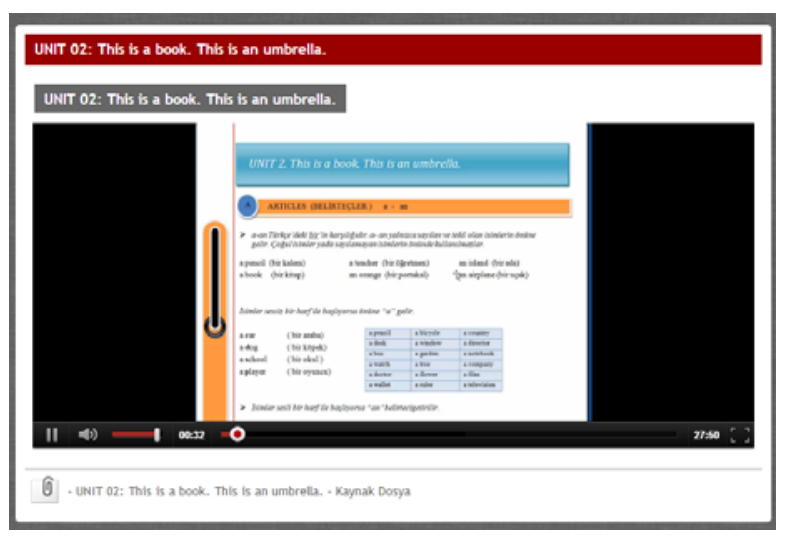

Figure 4. LMS Course Content Page

\section{B. Discussion Forum}

This is the place where teachers and students can meet in an interactive way.

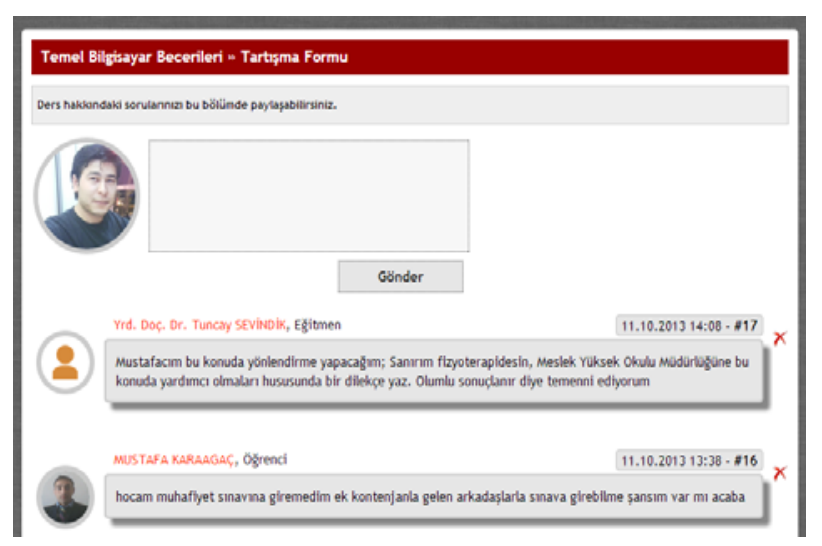

Figure 5. LMS Interactive Forum Page

\section{ANNOUNCEMENTS}

After publishing, all the announcements can be seen by the teachers and the students. All of those who read the announcements can be recorded on demand. The user accessed to the system can in no way reach to the course content without reading the announcement.

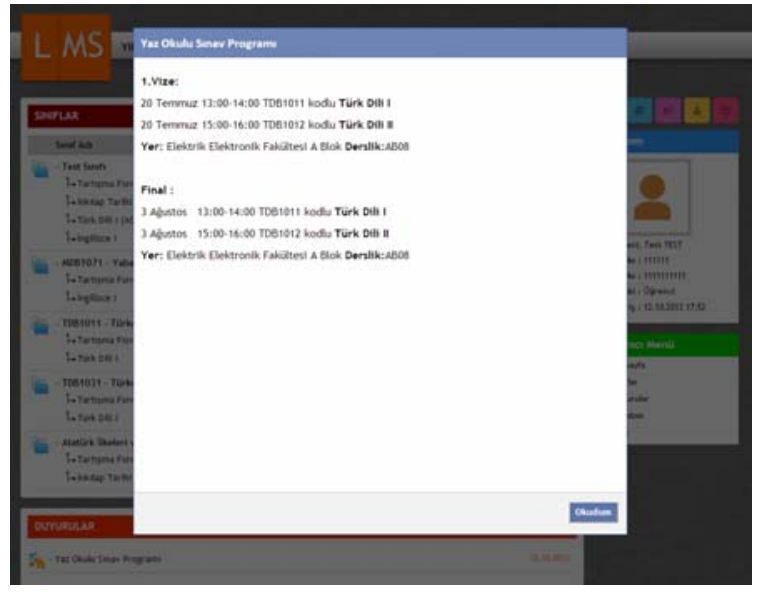

Figure 6. LMS Announcement Pop-up Page

\section{USER BEHAVIORS}

All the operations of the users in the system are recorded and can be listed on demand.

\begin{tabular}{|c|c|c|c|}
\hline \multicolumn{4}{|c|}{ Kullanic Rapor - EMRE KUNDURACI } \\
\hline Nick & Istem & Tarith & ip \\
\hline 1. 12066034 & çis yapt. & $04,10.201316: 07$ & 193.140 .1 .122 \\
\hline 2. 12066034 & EMRE KUNDURACI kullamcsintin profflini goruntuledi. & $04.10 .201316: 06$ & 193.140.1.122 \\
\hline 3. 12066034 & Tartisma formu formunu okudu. & $04.10 .201316: 06$ & 193.140 .1 .122 \\
\hline 4. 12066034 & Tartisma Formu formunu okusu. & $04,10.201216: 06$ & $193,140,1.122$ \\
\hline 5. 12066034 & Tarttşma Formu formuna ileti yard. & $04.10 .201316: 06$ & 193.140 .1 .122 \\
\hline 6. 12066034 & Tartopma formu formuna ileti yazt. & $04,10.201316: 06$ & $193.140,1.122$ \\
\hline 7. 12066034 & Tartigna Formu formunu okudu. & $04.10 .201316: 04$ & $193,140.1 .122$ \\
\hline Q. 12066034 & Girls yapt. & $04,10.201316: 04$ & 193.140 .1 .122 \\
\hline 9. 12066034 & çkis yaptt. & $01.10 .201318: 31$ & 193.255 .117 .185 \\
\hline 10. 12066034 & Tartisma Formu formunu okudu. & $01,10.201318: 29$ & 193.255 .117 .185 \\
\hline 11. 12066034 & Tartspma formu formunu okudu. & $01,10.201318: 29$ & $193.255 .117,185$ \\
\hline 12. 12066034 & Ders 02 : oil egitimini inceledi. & $01.10 .201318: 27$ & $193.255 .117,185$ \\
\hline 13. 12066034 & Ders 01: lletigim egitumini inceladi. & 01.10.2013 10:27 & 193.255 .117 .105 \\
\hline 14. 12066034 & Tartisma Formu formunu okudu. & $01.10 .201318: 26$ & $193.255,117,105$ \\
\hline 15. 12066034 & Tartigma formu formunu okudu. & $01.10 .201318: 26$ & 193.255 .117 .185 \\
\hline A. matrane & 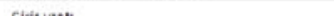 & 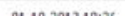 & 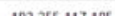 \\
\hline
\end{tabular}

Figure 7. LMS Log Record Page

\section{USER LIST}

The users can be recorded to the system one by one or all together or by using an Excel document. All the users are informed via e-mail including their access details to the system for confirmation of recording to the system. 


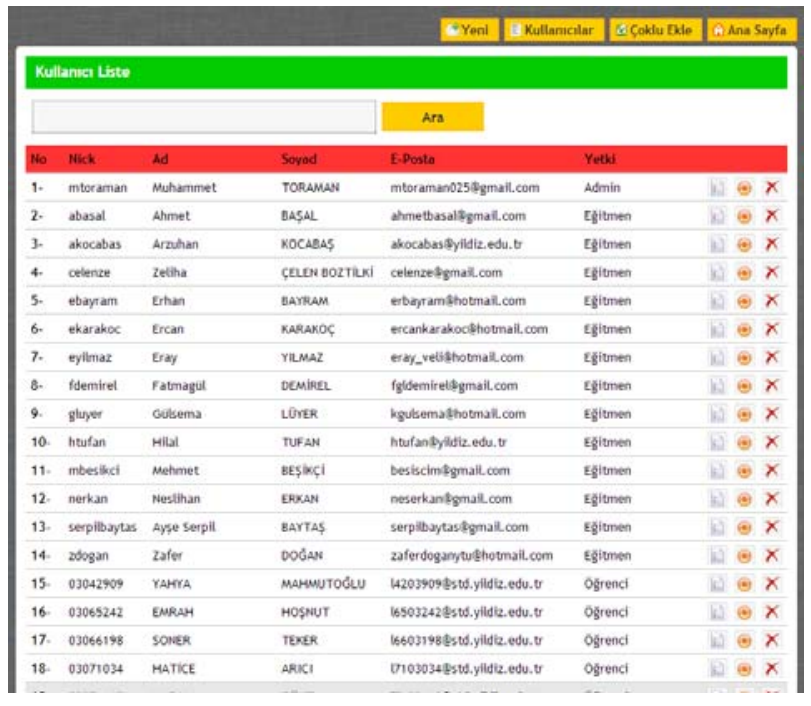

Figure 8.LMS Student Lit for the Courses

\section{E-MAIL}

User account information and discussion forum activities are sent to the users via e-mail..

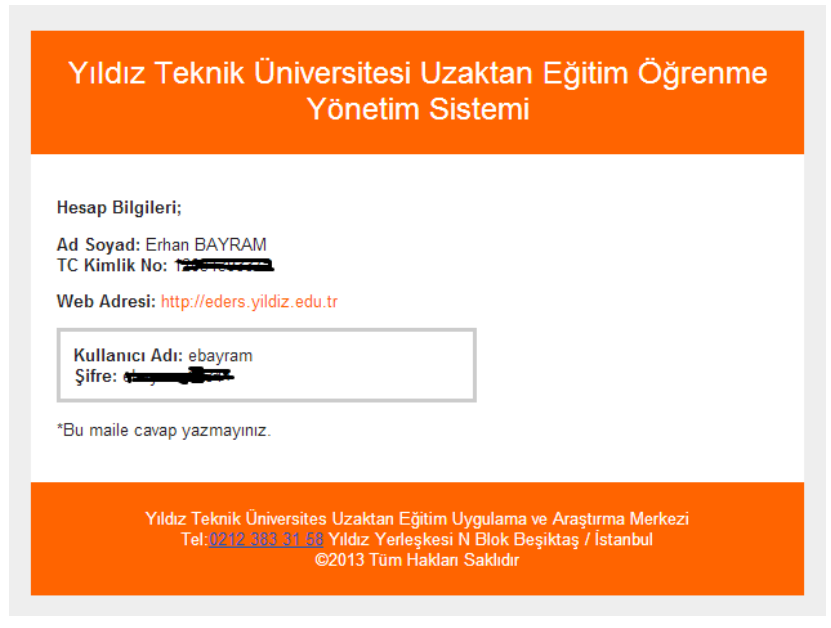

Figure 9. LMS Sent E-mail Screenshot

\section{CONCLUSION}

LMS is one of the most important aspects of distance education conducted web-based. It is a must for an organized delivery of the course content and other educational functions. This system is like a robust bridge between the teachers and the students that makes the education more effective. The LMS designed for Yildiz Technical University teaches us that before starting to design an LMS, it is logical to take into account the needs of the education institution and the learners. Thinking about the needs should be a good starting point to have an effective LMS meeting all those needs. Moreover, recording the behaviors of the users in the LMS will certainly be an important asset while developing and updating the system since these user behaviors give us the information about how the system is used and what features of the system are most or least used, giving us hints for the future improvement efforts on the system. Development is a continuing process; therefore recording user behaviors is crucial in this process.

Apart from using the discussion forums for the education purposes of the courses, they can be used as getting feedback related to the plusses of minuses of the system directly from its users. Such feedbacks will also provide invaluable information to the system designers for future improvements in the systems. No one can possible have more detailed information about the effectiveness and usefulness of the system other its users. Therefore, it is of vital importance to develop the system based on the data directly obtained by the users. This study shows the importance of the users for the development and improvement of LMS.

\section{REFERENCES}

[1] Bradley and etc, The Use of a Learning Management System (LMS) to Serve as the Virtual Common Space of a Network for the Scholarship of Teaching and Learning (SoTL) in an Academic Department, Journal of Educ. Sci. 2013, 3(2), 136-146

[2] What is Distance Learning?http://www.cdlponline.org/index.cfm? fuseaction=whati, Retrieved 2013

[3]Rouse, M. 2005, http://searchcio-midmarket.techtarget.com/ definition/distance-learnin, Retrieved 2013

[4]Watson, W. R., Watson, S.L. An Argument for Clarity: What are Learning Management Systems, What are They Not, and What Should They Become? Journal of TechTrends 51(2) (2007) 28-34

[5]Paulsen, M.F. (2002), Online Education Systems: Discussion and Definition of Terms, http://home.nettskolen.com/ morten 